\title{
Editorial
}

\section{Changing times: Social Theory \& Health into the second decade of the twenty-first century}

Social Theory \& Health (2011) 9, 1-2. doi:10.1057/sth.2010.14

The brief history of Social Theory \& Health has seen a transition or two, if none to match the changes in the social worlds it endeavours to reflect. The reconfiguring of geopolitics, the globalizing economy, novel types of post-national warfare, climate shifts, mass migration, religious resurgences and local social and cultural dislocation have occasioned a rethinking of many national welfare and health-care programmes and one way or another rippled out to impact on the prospects and lifestyles of millions of citizens-cum-clients-cum-consumers. Social Theory \& Health, it sometimes seems to its editors, has insinuated itself into an era of more-or-less continuous turmoil and unpredictability. We would encourage submissions, and especially comparative analyses, linking macro-, meso- and micro-social change to facets of health and health care.

Founded in the second half of 2003, Social Theory \& Health has steadily grown into a recognized companion resource complimenting other longerestablished international journals like Social Science \& Medicine, Sociology of Health \& Illness and Health. As a key outlet for theory-oriented papers it has become part of the academic furniture. Content aside, it has in its short life seen two obvious transitions of its own. First, it has become affiliated to the European Society for Health and Medical Sociology (ESHMS), a process negotiated with the help of Johannes Siegrist and enthusiastically endorsed by Guido Giarelli during his tenure as President of ESHMS. Plenary lectures and selected papers from the (biannual) ESHMS conference in Ghent in 2010 will be published as a 'special issue' later this year. And second, Ruth Graham from Newcastle University has become a fourth editor. Ruth's enthusiastic involvement has given a welcome boost to the three founding editors and been a source of new energy and ideas.

Inspection of the first 30 issues of Social Theory \& Health (from May 2003 to November 2010), surely some kind of anniversary, reveals the following breakdown: three annual lectures (Nikolas Rose, Johannes Siegrist and Mike Bury, with Carol Thomas's in the pipeline and Roy Bhaskar's to come later in 2011); 124 original articles; two critiques; six commentaries; three explications of concepts ('medicalization', 'generation and cohort' and 'empowerment'); one 
debate paper; four editorials; two guest editorials; and 11 book reviews. Two hundred and twelve authors from 15 countries have contributed, just under half from the United Kingdom and Ireland and nearly a third from the United States and Canada.

Three principle observations arise out of these data. First, reiterating previous editorials, we remain concerned about the lack of representation of colleagues from developing societies (a single paper in 7 years - from South Africa - is disappointing); second, we recognize that this lack of representation from developing societies is in part a failure on our part (the message to those in developing societies for whom English is a second language but one necessary for advancement is: lean on your institutions to facilitate academic careers, and then enter into discussions with journal editors); and third, and perhaps more prosaically, we acknowledge a relative paucity of book reviews, although in this case we would plead constraints of space in the past that are likely to ease in the future.

At the start of the second decade of the twenty-first century we are on the cusp of process innovation, courtesy of Palgrave Macmillan. First, we shall from this year onwards have more pages available to distribute between our four issues per annum. This is particularly welcome given our steady flow of excellent contributions: we have on occasions in the past been obliged to ask authors to wait longer than they or we would wish to see their work in print. Second, accepted articles will now be published online ahead of inclusion in an online/print issue and will be fully citable. As editors we very much welcome these developments.

Any journal is dependent on the quality of the manuscripts submitted to it and of the advisers and referees its editors are able to call on. As ever we extend our grateful thanks to our many colleagues. We are gratified too by the growing numbers of colleagues who are downloading and citing papers published in Social Theory \& Health. Importantly, our appreciation extends to our colleagues at Palgrave Macmillan. We have liaised with several publishing editors over the years, all of them entirely committed to Social Theory \& Health. The current publishing editor, Neil Henderson, is no exception. Jane Torr, our production manager, has been omnipresent since 2003 and it is she who 'makes it all happen'. We are indebted to them both.

Graham Scambler

Paul Higgs

Richard Levinson

Ruth Graham 